\title{
New record of Amphisbaena fuliginosa (Squamata, Amphisbaenidae) for the Cerrado Biome, in an area of extensive cattle ranching
}

\author{
Frederico Gemesio Lemos ${ }^{1,3}$ \& Kátia Gomes Facure ${ }^{2}$ \\ Biota Neotropica $v 7(n 1)$ \\ http://www.biotaneotropica.org.br/v7n1/pt/abstract?short-communication+bn03607012007 \\ Data Received 14/11/06 \\ Revised 12/01/07 \\ Accepted 31/03/07 \\ ${ }^{1}$ Programa de Pós-Graduação em Ecologia e Conservação de Recursos Naturais da \\ Universidade Federal de Uberlândia, CEP 38400-902 Uberlândia, MG, Brasil, \\ e-mail: gemesio@uol.com.br \\ ${ }^{2}$ Laboratório de Taxonomia, Ecologia Comportamental e Sistemática de Anuros Neotropicais, \\ Universidade Federal de Uberlândia, CEP 38400-902 Uberlândia, MG, Brasil \\ ${ }^{3}$ Corresponding author: Kátia Gomes Facure, e-mail: thoropa@inbio.ufu.br
}

\begin{abstract}
Lemos, F.G. \& Facure, K.G. New record of Amphisbaena fuliginosa (Squamata, Amphisbaenidae) for the Cerrado Biome, in an area of extensive cattle ranching. Biota Neotrop. Jan/Apr 2007 vol. 7, no. 1 http://www.biotaneotropica.org.br/v7n1/pt/abstract?short-communication+bn03607012007 ISSN 1676-0603.

Samples of Amphisbaena fuliginosa from the Cerrado biome are scarce and additional data are needed to clarify the geographic distribution and patterns of differentiation of this species. During field works at a cattle farm in the south of the state of Goiás, Central Brazil, we found an adult individual of A. fuliginosa. Our specimen represents the southernmost record for the species, extending its distribution $150 \mathrm{~km}$. The color is similar to that described for other specimens from Goiás state, corroborating the uniform pattern observed for Cerrado populations. We suggest that the fossorial habits of A. fuliginosa may allow its occurrence in anthropogenic habitats by offering protection against the changes in natural vegetation.

Keywords: Central Brazil, color pattern, environmental changes, fossorial habits, geographic distribution, herpetofauna.

\section{Resumo}

Lemos, F.G. \& Facure, K.G. Novo registro de Amphisbaena fuliginosa (Squamata, Amphisbaenidae) para o Bioma Cerrado, em uma área de criação extensiva de gado. Biota Neotrop. Jan/Apr 2007 vol. 7, no. 1 http://www.biotaneotropica.org.br/v7n1/pt/abstract?short-communication+bn03607012007 ISSN 1676-0603.

Amostras de Amphisbaena fuliginosa do Bioma Cerrado são escassas e dados adicionais são necessários para esclarecer a distribuição geográfica e os padrões de diferenciação dessa espécie. Durante trabalhos de campo em uma fazenda de gado no sul de Goiás, Brasil central, nós encontramos um indivíduo adulto de A. fuliginosa. Nosso espécime representa o registro mais ao sul para a espécie, estendendo a sua distribuição $150 \mathrm{~km}$. A coloração é similar àquela descrita para outros espécimes de Goiás, corroborando o padrão uniforme observado para as populações do Cerrado. Nós sugerimos que o hábito fossorial de A. fuliginosa pode permitir sua ocorrência em habitats antrópicos, por oferecer proteção contra as mudanças na vegetação natural.
\end{abstract}

Palavras-chave: alterações ambientais, Brasil Central, distribuição geográfica, hábito fossorial, herpetofauna, padrão de coloração. 


\section{Introduction}

The Cerrado is the second largest Neotropical biome, a mosaic of plant formations ranging from open areas, such as campos and veredas, to more dense formations, such as gallery forests and semideciduous forests (Oliveira-Filho \& Ratter 2002). About $80 \%$ of its total area has been modified by human activities (Alho \& Martins 1995, Myers et al. 2000), with the east and southeast regions being the most highly fragmented and occupied by agriculture, cattle ranching and urban expansion (Cavalcanti \& Joly 2002). In spite of most of the Cerrado's natural areas being converted to human use (Cavalcanti \& Joly 2002), animal communities remain highly diversified (Colli et al. 2002, Macedo 2002, Marinho-Filho et al 2002).

Amphisbaenians are squamates of early evolutionary origin specialized to a fossorial life (Navas et al. 2004). Living species are distributed in southern Europe, northern Africa, Asia Minor and South America (Gans 2005). At present, 15 species are known to occur in the Cerrado biome, eight of which are endemic (Colli et al. 2002). Most of the available information on the natural history of the Cerrado herpetofauna is restricted to lizards and anurans, and practically no information is available for amphisbaenians (Colli et al. 2002).

Amphisbaena fuliginosa Linnaeus (1758) was previously understood to be restricted to forested areas of Amazonia (Chalkidis 2000, Vanzolini 2002), but it was recently reported in the open formations of the Brazilian Cerrado (Colli et al. 2002, Vanzolini 2002). In forested areas, the species exhibits well-defined and characteristic color patterns over broad areas that are separated by narrow transition belts (Vanzolini 2002). Since samples from the Cerrado are few (only 13 specimens), and restricted to two localities (Piracanjuba and Serra da Mesa, Goiás state) (Vanzolini 2002), additional data may clarify the geographic distribution and patterns of differentiation of this species.

During field works at a cattle farm in the south of the state of Goiás, Central Brazil, we found a specimen of A. fuliginosa. The aims of the present study are to redefine the distributional range of this species and to present complementary data on the color pattern of Cerrado populations.

\section{Material and Methods}

Field work was conducted at Limoeiro Ranch ( $18^{\circ} 15^{\prime} 47^{\prime \prime} \mathrm{S} 48^{\circ}$ 09' 04" W; $561 \mathrm{~m}$ above sea level), Cumari municipality, south of Goiás state, Central Brazil. The Limoeiro Ranch is a cattle farm of approximately 500 ha located about $20 \mathrm{~km}$ south from the center of Cumari and $6 \mathrm{~km}$ from the Paranaíba River (south the state boundary). Most of the area (90\%) has been covered with pasture (Brachiaria sp.) for at least ten years. However, it still contains small patches of original vegetation, such as gallery forest and cerrado sensu stricto.

The specimen was photographed and released safely in the same place it was found.

\section{Results}

The specimen was found on 22 April 2006 about 9:00 AM in an orchard near the ranch house. Body length was ca. $30 \mathrm{~cm}$. The ground color was purplish and the dorsum had the black pattern typical of the species (Figure 1), with an almost interrupted lighter collar in each side of the nape (Figure 2).

\section{Discussion}

Our specimen represents the southernmost record of A. fuliginosa and the collecting site is the third locality known in the Cerrado biome for the species, extending its distribution approximately $150 \mathrm{~km}$ south of Piracanjuba, GO (Figure 3). The color pattern of our specimen is

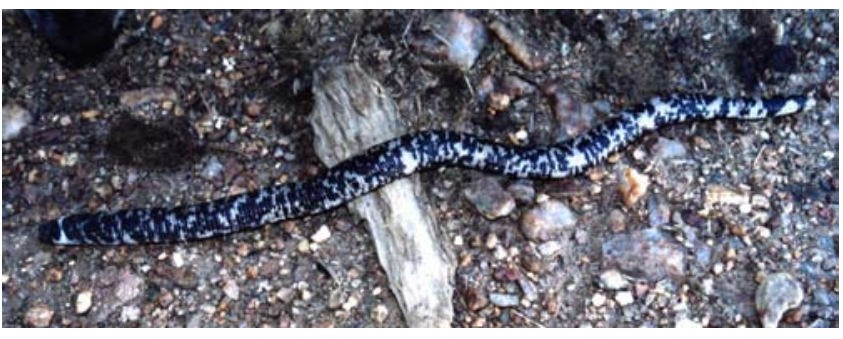

Figure 1. Dorsal color pattern of the specimen of Amphisbaena fuliginosa from Limoeiro Ranch, Cumari municipality, Goiás state, Central Brazil. (Photograph by F. G. Lemos).

Figura 1. Padrão de coloração dorsal do espécime de Amphisbaena fuliginosa da Fazenda Limoeiro, Município de Cumari, Estado de Goiás, Brasil Central. (Foto de F. G. Lemos).

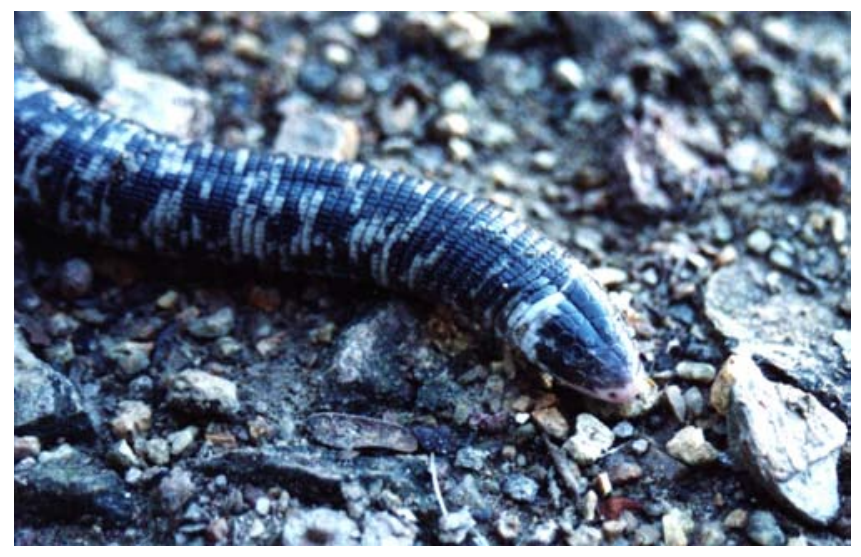

Figure 2. Detail of the head of the specimen of Amphisbaena fuliginosa from Limoeiro Ranch, Cumari municipality, Goiás state, Central Brazil. (Photograph by F. G. Lemos).

Figura 2. Detalhe da cabeça do espécime de Amphisbaena fuliginosa da Fazenda Limoeiro, Município de Cumari, Estado de Goiás, Brasil Central. (Foto de F. G. Lemos).

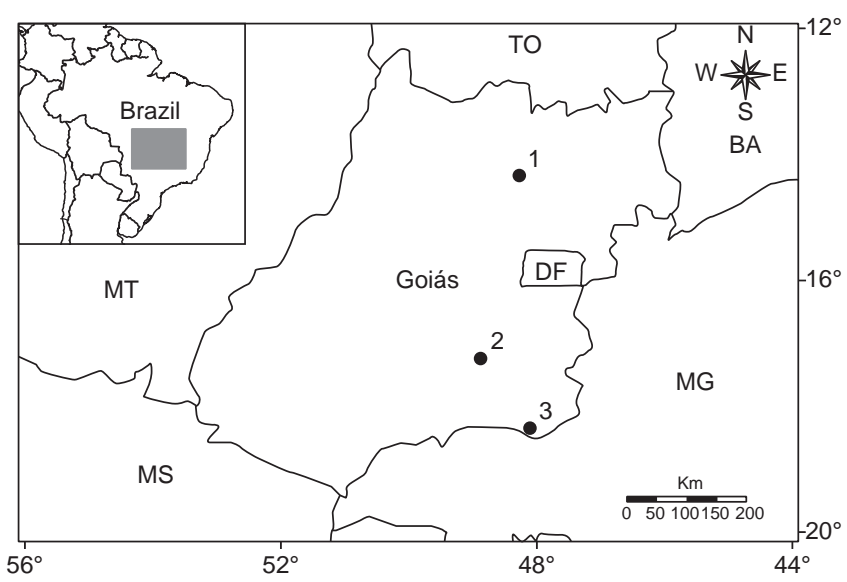

Figure 3. Map illustrating the known distribution of Amphisbaena fuliginosa in the Goiás state, Central Brazil. 1) Serra da Mesa; 2) Piracanjuba; 3) Cumari (new record).

Figura 3. Mapa ilustrando a distribuição conhecida de Amphisbaena fuliginosa no Estado de Goiás, Brasil Central. 1) Serra da Mesa; 2) Piracanjuba; 3) Cumari (novo registro).

similar to that described by Vanzolini (2002) for other specimens from Goiás state, corroborating the uniform color pattern observed for Cerrado populations (Vanzolini 2002). 
Richness and distribution of the herpetofauna in Cerrado biome is probably under estimated (Bini et al. 2006), and many species have been recently described (e.g., Silva et al. 2005, Torres-Carvajal 2005). The discovery of A. fuliginosa so far south of its previously known localities indicates that this species have a wider distribution in this biome.

It is believed that A. fuliginosa originated in Amazonia and colonized the Cerrado more recently (Vanzolini 2002). The range expansion of this species may be related to its fossorial habits (Vanzolini 2002). Besides making it easier for the species to cross the ecological barriers between the two biomes, the fossorial habits of A. fuliginosa may also allow its occurrence in anthropogenic habitats such as the Limoeiro Ranch by offering protection against the changes in natural vegetation.

\section{Acknowledgments}

We are grateful to Dr. Nelson Jorge da Silva Jr. for verifying specimen identification and revising an early draft of this manuscript and to Nilson Floriano Lemos for his help in the field work. A. N. Costa prepared the maps drawings and A. A. Giaretta made valuable suggestions. The Coordenação de Aperfeiçoamento de Pessoal de Nível Superior (CAPES) provided a graduate scholarship to F. G. Lemos and a ProDoc fellowship and financial support to K. G. Facure.

\section{References}

ALHO, C.J.R. \& MARTINS, E.S. 1995. De grão em grão o Cerrado perde espaço. WWF-Brasil, Brasília.

BINI, L.M., DINIZ-FILHO, J.A.F., RANGEL, T.F.L.V.B., BASTOS, R.P \& PINTO, M.P. 2006. Challenging Wallacean and Linnean shortfalls: knowledge gradients and conservation planning in a biodiversity hotspot. Diversity Distrib. 12:475-482.

CAVALCANTI, R.B. \& JOLY, C.A. 2002. Biodiversity and conservation priorities in the Cerrado region. In The Cerrados of Brazil: Ecology and Natural History of a Neotropical Savanna (P.S. Oliveira \& R.J. Marquis, eds.). Columbia University Press, New York, p. 351-367.

CHALKIDIS, H.M. 2000. Amphisbaena fuliginosa varia. Herpetol. Rev. $31: 253$.

COLLI, G.R., BASTOS, R.P. \& ARAÚJO, A.F.B. 2002. The Character and Dynamics of the Cerrado Herpetofauna. In The Cerrados of Brazil: Ecology and Natural History of a Neotropical Savanna (P.S. Oliveira \& R.J. Marquis, eds.). Columbia University Press, New York, p. 223-241.

GANS, C. 2005. Checklist and bibliography of the Amphisbaena of the world. Bull. Am. Mus. Nat. Hist. 289:1-130.

MACEDO, R.H.F. 2002. The avifauna: Ecology, biogeography, and behavior In The Cerrados of Brazil: Ecology and Natural History of a Neotropical Savanna (P.S. Oliveira \& R.J. Marquis, eds.). Columbia University Press, New York, p. 242-265.
MARINHO FILHO, J., RODRIGUES, F.H.G. \& JUAREZ, K.M. 2002. The Cerrado mammals: diversity, ecology and natural history. In The Cerrados of Brazil: Ecology and Natural History of a Neotropical Savanna (P.S. Oliveira \& R.J. Marquis, eds.). Columbia University Press, New York, p. 266-284.

MYERS, N., MITTERMEIER, R.A., MITTERMEIER, C.G., FONSECA, G.A.B. \& KENT, J. 2000. Biodiversity hotspots for conservation priorities. Nature 403:853-858.

NAVAS, C.A., ANTONIAZZI, M.M., CARVALHO, J.E., CHAUI-BERLINK, J.G., JAMES, R.S., JARED, C., KHOLSDORF, T., PAI-SILVA, M.D. \& WILSON, R.S. 2004. Morphological and physiological specialization for digging in amphisbaenians, an ancient lineage of fossorial vertebrates. J. Exp. Biol. 207:2433-2441

OLIVEIRA-FILHO, A.T. \& RATTER, J.A. 2002. Vegetation physiognomies and woody flora of the Cerrado Biome. In The Cerrados of Brazil: Ecology and Natural History of a Neotropical Savanna (P.S. Oliveira \& R.J. Marquis, eds.). Columbia University Press, New York, p. 91-120.

SILVA JR., N.J., SILVA, H.L.R., RIBEIRO, R.S., SOUZA, I. \& SOUZA, C.A. 2005. Uma nova espécie do gênero Atractus Wagler, 1928 (Colubridae: Dipsadinae) do Cerrado do Brasil Central. Pap. Avulsos Zool 45:33-39.

TORRES-CARVAJAL, O. 2005. A new species of Stenocercus (Squamata, Iguanidae) from central-western Brazil with a key to Brazilian Stenocercus. Phyllomedusa 4:123-132.

VANZOLINI, P.E. 2002. A second note on the geographical differentiation of Amphisbaena fuliginosa L., 1758 (Squamata, Amphisbaenidae), with a consideration of the forest refuge model of speciation. An. Acad. Bras. Ciênc. 74:609-648.

Title: New record of Amphisbaena fuliginosa (Squamata, Amphisbaenidae) for the Cerrado Biome, in an area of extensive cattle ranching.

Authors: Lemos, FG e Facure, KG

Biota Neotropica, Vol.7 (number 1): 2007

http://www.biotaneotropica.org.br/v7n1/pt/abstract?shortcommunication+bn03607012007

Data Received 14/11/06 - Revised 12/01/07 -

Accepted 31/03/07

ISSN 1676-0603 